ISSN 1420-3049

www.mdpi.com/journal/molecules

Article

\title{
Direct Enzymatic Route for the Preparation of Novel Enantiomerically Enriched Hydroxylated $\beta$-Amino Ester Stereoisomers
}

\author{
Enikő Forró ${ }^{1}$, László Schönstein ${ }^{1}$, Loránd Kiss ${ }^{1}$, Alberto Vega-Peñaloza ${ }^{2}$, Eusebio Juaristi ${ }^{2}$ \\ and Ferenc Fülöp ${ }^{1,3, *}$
}

1 Institute of Pharmaceutical Chemistry, University of Szeged, H-6720 Szeged, Eötvös u. 6, Hungary

2 Departamento de Química, Centro de Investigación y de Estudios Avanzados del Instituto

Politécnico Nacional, Av. Instituto Politécnico Nacional 2508 Col. San Pedro Zacatenco, 07360

México, D.F. Apartado Postal 14-740, 07000, D.F., Mexico

3 Research Group of Stereochemistry of the Hungarian Academy of Sciences, University of Szeged,

H-6720 Szeged, Eötvös u. 6, Hungary

* Author to whom correspondence should be addressed; E-Mail: fulop@pharm.u-szeged.hu;

Tel.: (+36)62-545564; Fax: (+36)62-545705.

Received: 6 May 2010; in revised form: 25 May 2010 / Accepted: 28 May 2010 /

Published: 1 June 2010

\begin{abstract}
Enantiomerically enriched hydroxy-substituted $\beta$-amino esters have been synthesized through CAL-B-catalyzed enantioselective hydrolysis in organic media. Moderate to good enantiomeric excess values $(e e \geq 52 \%)$ were obtained when the CAL-Bcatalyzed reactions were performed in $t$-BuOMe, at $60{ }^{\circ} \mathrm{C}$ with 0.5 equiv. of added $\mathrm{H}_{2} \mathrm{O}$ as nucleophile.
\end{abstract}

Keywords: $\beta$-amino ester; stereoisomer; enzyme; hydrolysis; hydroxylation; organic solvent; enantioselective

\section{Introduction}

A number of cyclic $\beta$-amino acids exhibit biological activity (e.g. cispentacin $[1,2]$ and Icofungipen $[3,4]$ ), and in addition they have also been used in peptide (modified activities and stabilities [5] and well-defined three-dimensional structures [6-9]), in heterocyclic [10-13] and combinatorial [14-16] 
chemistry, and in drug research $[9,17,18]$. Hydroxylated $\beta$-amino acids represent a valuable class of amino acids, due to their importance from both biological and chemical aspects. In recent years, acyclic hydroxylated $\beta$-amino acids have attracted much attention especially following their recognition as an important class of compounds in the design and synthesis of potential pharmaceutical drugs [e.g., Taxol ${ }^{\circledR}$ (paclitaxel) and its analogue Taxotère ${ }^{\circledR}$ (docetaxel)] [17,19-21]. Among the carbocyclic $\beta$-amino acids a number of hydroxylated $\beta$-amino acid derivatives present antibiotic (e.g., oryzoxymycin [22]) or antifungal activity, and are building blocks for pharmaceutically important natural substances such as fortamine, chryscandin, pentopyranamine, gougerotin and blasticidin [20,23].

Enzymatic methods for the preparation of several enantiomerically pure hydroxy-substituted carbocyclic $\beta$-amino acids or their derivatives have been published, but in those syntheses the enantioselective enzymatic step was performed for the preparation of starting $\beta$-amino acids [24-27]. In contrast, in this work the aim was to introduce the chirality on the last step on the synthetic sequence leading to hydroxy-substituted $\beta$-amino esters. Our earlier extensive investigations on enzyme-catalyzed enantioselective hydrolysis of both carbocyclic [28] and acyclic [29-31] $\beta$-amino esters suggested the possibility of direct lipase-catalyzed resolution of hydroxy-substituted $\beta$-amino esters $\left(1 R^{*}, 2 S^{*}, 5 S^{*}\right)-( \pm)-4, \quad\left(1 S^{*}, 2 S^{*}, 5 R^{*}\right)-( \pm)-5, \quad\left(1 S^{*}, 2 S^{*}, 5 S^{*}\right)-( \pm)-6$ and $\left(1 S^{*}, 2 S^{*}, 5 R^{*}\right)-( \pm)-\mathbf{1 0}$, through enantioselective enzymatic hydrolysis.

\section{Results and Discussion}

2.1. Synthesis of hydroxy-substituted racemic $\beta$-amino esters (1R*,2S*,5S*)-( \pm )- 4 , (1S *,2S*,5S*)-( \pm )$5,(1 \mathrm{~S} *, 2 \mathrm{~S} *, 5 \mathrm{~S} *)-( \pm)-6$ and $(1 \mathrm{~S} *, 2 \mathrm{~S} *, 5 \mathrm{R} *)-( \pm)-10$

The selective synthesis of the hydroxylated amino ester stereoisomers with a cyclohexene framework has been accomplished starting from $\mathrm{N}$-Boc protected cis- or trans-2-aminocyclohex-3enecarboxylic acid [32] and was based on stereoselective iodolactonization followed by dehydroiodination and lactone opening. Thus, amino acid $(1 R, 2 S)-( \pm)-1$ on treatment with $\mathrm{KI} / \mathrm{I}_{2}$ in the presence of $\mathrm{NaHCO}_{3}$ gave regioselectively iodolactone $\left(1 R^{*}, 2 S^{*}, 4 S^{*}, 5 S^{*}\right)-( \pm)-\mathbf{2}$, which was then subjected to dehydroiodination with DBU under basic conditions, affording unsaturated lactone $\left(1 R^{*}, 2 S^{*}, 5 S^{*}\right)-( \pm)-3$ (Scheme 1). The hydroxyl function in the cyclohexene skeleton was introduced by lactone opening of $\left(1 R^{*}, 2 S^{*}, 5 S^{*}\right)-( \pm)-3$ with $\mathrm{NaOEt}$. When the reaction was performed in EtOH at $0{ }^{\circ} \mathrm{C}$ for $1 \mathrm{~h}$ the all-cis-5-hydroxlated amino ester $\left(1 R^{*}, 2 S^{*}, 5 S^{*}\right)-( \pm)-4$ was formed in good yield. By contrast, upon reaction with $\mathrm{NaOEt}$ at $20{ }^{\circ} \mathrm{C}$ for $20 \mathrm{~h}$ lactone $\left(1 R^{*}, 2 S^{*}, 5 S^{*}\right)-( \pm)-3$ underwent epimerization at C-1 to give the hydroxylated amino ester stereoisomer $\left(1 S^{*}, 2 S^{*}, 5 S^{*}\right)-( \pm)-5$ (Scheme 1). The desired saturated analog of $\left(1 S^{*}, 2 S^{*}, 5 S^{*}\right)-( \pm)-6$ was readily prepared in good yield by Pd catalyzed hydrogenation performed at room temperature and atmospheric pressure.

Other hydroxylated stereoiomers of $\left(1 R^{*}, 2 S^{*}, 5 S^{*}\right)-( \pm)-4$ and $\left(1 S^{*}, 2 S^{*}, 5 S^{*}\right)-( \pm)-5$ could be prepared from $N$-Boc-protected amino acid $\left(1 S^{*}, 2 S^{*}\right)-( \pm)-7$ when submitted to iodolatonization, dehydroiodination, followed by lactone ring-opening with $\mathrm{NaOEt}$ to furnish selectively hydroxylated amino ester stereoisomer $\left(1 S^{*}, 2 S^{*}, 5 R^{*}\right)-( \pm)-\mathbf{1 0}$ (Scheme 2$)$. 
Scheme 1. Synthesis of $\left(1 R^{*}, 2 S^{*}, 5 S^{*}\right)-( \pm)-4,\left(1 S^{*}, 2 S^{*}, 5 S^{*}\right)-( \pm)-5$ and $\left(1 S^{*}, 2 S^{*}, 5 S^{*}\right)-( \pm)-6$.

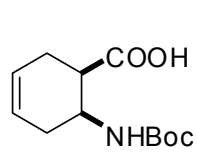

$\left(1 R^{\star}, 2 S^{*}\right)-( \pm)-1$

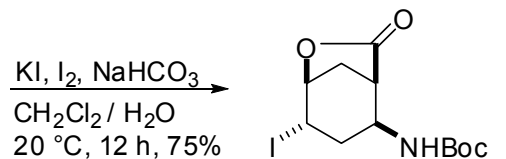

$\left(1 R^{*}, 2 S^{*}, 4 S^{*}, 5 S^{\star}\right)-( \pm)-2$

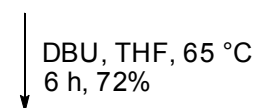

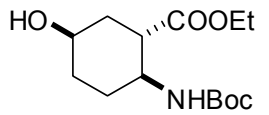

$\left(1 S^{*}, 2 S^{*}, 5 S^{*}\right)-( \pm)-6$

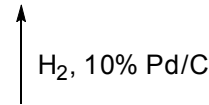

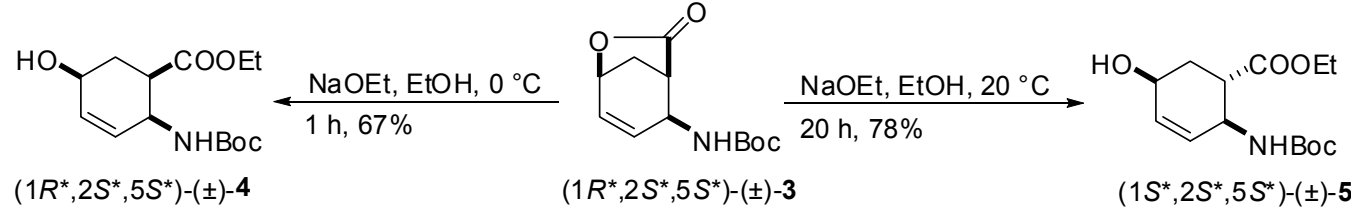

Scheme 2. Synthesis of $\left(1 S^{*}, 2 S^{*}, 5 R^{*}\right)-( \pm)-\mathbf{1 0}$.

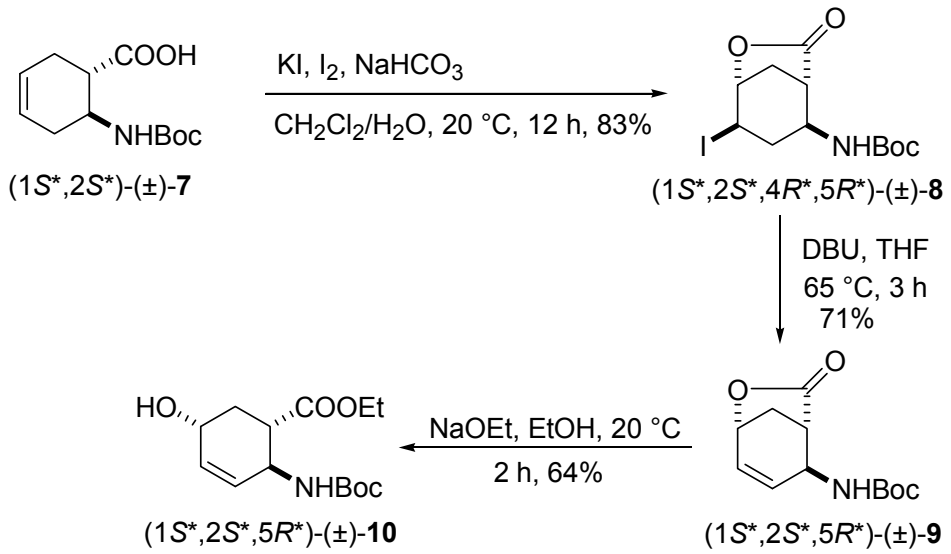

2.2. Enzymatic hydrolysis of hydroxy-substituted $\beta$-amino esters ( $\left.1 \mathrm{~S}^{*}, 2 \mathrm{R} *, 5 \mathrm{R} *\right)-( \pm)-4,(1 \mathrm{~S} *, 2 \mathrm{~S} *, 5 \mathrm{~S} *)-$ $( \pm)-5,(1 \mathrm{~S} *, 2 \mathrm{~S} *, 5 \mathrm{~S} *)-( \pm)-6$ and $(1 \mathrm{~S} *, 2 \mathrm{~S} *, 5 \mathrm{R} *)-( \pm)-10$

On the basis of our earlier results on the enantioselective hydrolyses of $\beta$-amino esters using CAL-B and lipase PS in an organic solvent [28-31] we carried out enzymatic screening experiments relating to the hydrolysis of $\left(1 S^{*}, 2 S^{*}, 5 R^{*}\right)-( \pm)-10$ (Scheme 3 ) with 0.5 equiv. of $\mathrm{H}_{2} \mathrm{O}$ in $i-\mathrm{Pr}_{2} \mathrm{O}$ (Table 1 , entries 1 and 11-15). Excepting lipase AK (Pseudomonas flurescens), which practically did not show any selectivity, all the other lipases tested [CAL-A (Candida antarctica lipase A), CAL-B (Candida antarctica lipase B), lipases PS (Burkholderia cepacis), AY (Candida rugosa) and PPL (porcine pancreatic lipase)] all showed catalytic activity, but only CAL-B catalyzed the reaction at $60{ }^{\circ} \mathrm{C}$ with moderate enantioselectivity (ee $e_{\text {substrate }} 48 \%$ after $48 \mathrm{~h}$ ). As it was later confirmed, the majority of the antipodes of unreacted $\beta$-amino acid ethyl ester enantiomers were consumed in side-reactions (polymerization).

In order to enhance the observed enantioselectivity, several solvents were tested in the CAL-Bcatalyzed hydrolysis of $\left(1 S^{*}, 2 S^{*}, 5 R^{*}\right)-( \pm)-10$ at $60{ }^{\circ} \mathrm{C}$ (Table 1 , entries $\left.2-5\right)$. It could be appreciated that the reaction proceeded more slowly and less enantioselectively in $n$-hexane and 1,4-dioxane (entries 2 and 4), with better $E$ and comparable reaction rate in toluene (entry 3 ) and with considerably higher $E$ and higher reaction rate in $t$-BuOMe (entry 5) relative to $i \operatorname{Pr}_{2} \mathrm{O}$ (entry 1 ). 
Scheme 3. Enzymatic hydrolysis of $\left(1 S^{*}, 2 R^{*}, 5 R^{*}\right)-( \pm)-4, \quad\left(1 S^{*}, 2 S^{*}, 5 S^{*}\right)-( \pm)-5$, $\left(1 S^{*}, 2 S^{*}, 5 S^{*}\right)-( \pm)-6$ and $\left(1 S^{*}, 2 S^{*}, 5 R^{*}\right)-( \pm)-10$.<smiles>CCOC(=O)[C@H]1C[C@@H](O)C=C[C@H]1NC(=O)OCc1ccccc1</smiles>

$\left(1 S^{*}, 2 R^{*}, 5 R^{*}\right)-( \pm)-4$<smiles>CCOC(=O)[C@H]1C[C@@H](O)C=C[C@H]1N(C(=O)OCC)C(C)(C)C</smiles>

$\left(1 S^{*}, 2 S^{*}, 5 S^{*}\right)-( \pm)-5$

$\left(1 S^{*}, 2 S^{*}, 5 S^{*}\right)-( \pm)-6$

$\left(1 S^{*}, 2 S^{*}, 5 R^{*}\right)-( \pm)-10$<smiles>CCOC(=O)C1CC(O)C=CC1NC(C)(C)C</smiles>

$\left(1 S^{\star}, 2 R^{*}, 5 R^{*}\right)-( \pm)-4$
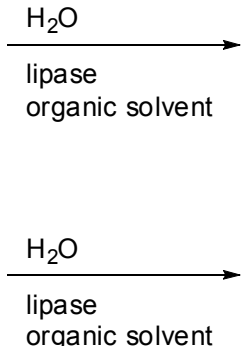

organic solvent

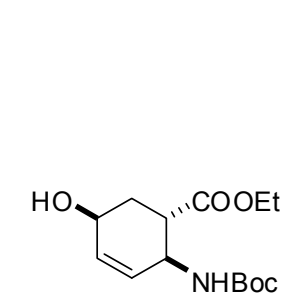

$\left(1 S^{*}, 2 S^{*}, 5 S^{*}\right)-( \pm)-5$<smiles>CCOC(=O)[C@H]1C[C@@H](O)C=C[C@H]1NC(=O)OCc1ccccc1</smiles>

$(1 R, 2 S, 5 S)-4$<smiles>CCOC(=O)[C]1C[C@@H](O)C=C[C@H]1N(OC(=O)O)C(C)(C)C</smiles>

(1S, 2S, 5S)-5

$(1 S, 2 S, 5 S)-6$

$(1 S, 2 S, 5 R)-10$

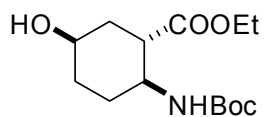

$\left(1 S^{*}, 2 S^{*}, 5 S^{*}\right)-( \pm)-6$

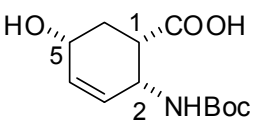

$(1 S, 2 R, 5 R)-11$

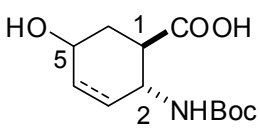

$(1 R, 2 R, 5 R)-12$

$(1 R, 2 R, 5 R)-13$

$(1 R, 2 R, 5 S)-14$

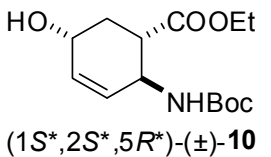

Table 1. Conversion and enantioselectivity of enzymatic hydrolysis of $\left(1 S^{*}, 2 S^{*}, 5 R^{*}\right)-( \pm)-10^{\mathrm{a}}$.

\begin{tabular}{|c|c|c|c|c|c|c|c|c|c|}
\hline Entry & Enzyme & $\begin{array}{l}\text { Quantity } \\
\text { of enzyme } \\
\left(\mathrm{mg} \mathrm{mL}^{-1}\right)\end{array}$ & $\begin{array}{l}\text { Temperatu } \\
\text { re }\left({ }^{\circ} \mathrm{C} .\right)\end{array}$ & Solvent & $\begin{array}{c}\text { Time } \\
\text { (h) }\end{array}$ & $\begin{array}{c}\text { Conv. }^{\mathrm{b}} \\
(\%)\end{array}$ & $\begin{array}{l}e e_{\mathrm{S}}^{\mathrm{c}} \\
(\%)\end{array}$ & $\begin{array}{l}e e_{\mathrm{P}}^{\mathrm{d}} \\
(\%)\end{array}$ & $E^{\mathrm{b}}$ \\
\hline 1 & CAL-B & 30 & 60 & $i \mathrm{Pr}_{2} \mathrm{O}$ & 48 & 37 & 48 & 82 & 16 \\
\hline 2 & CAL-B & 30 & 60 & $n$-hexane & 48 & 24 & 18 & 58 & 4 \\
\hline 3 & CAL-B & 30 & 60 & toluene & 48 & 35 & 48 & 91 & 34 \\
\hline 4 & CAL-B & 30 & 60 & 1,4-dioxane & 48 & 25 & 16 & 48 & 3 \\
\hline 5 & CAL-B & 30 & 60 & $t$-BuOMe & 48 & 45 & 75 & 91 & 48 \\
\hline 6 & CAL-B & 30 & 50 & $t$-BuOMe & 48 & 35 & 47 & 86 & 21 \\
\hline 7 & CAL-B & 30 & 40 & $t$-BuOMe & 48 & 36 & 46 & 81 & 15 \\
\hline 8 & CAL-B & 30 & 70 & $t$-BuOMe & 40 & 35 & 44 & 82 & 16 \\
\hline 9 & CAL-B & 50 & 60 & $t$-BuOMe & 40 & 40 & 53 & 81 & 16 \\
\hline 10 & CAL-B & 75 & 60 & $t$-BuOMe & 40 & 42 & 60 & 83 & 20 \\
\hline 11 & Lipase PS ${ }^{\mathrm{e}}$ & 30 & 45 & $i \mathrm{Pr}_{2} \mathrm{O}$ & 48 & 22 & 10 & 35 & 2 \\
\hline 12 & CAL-A ${ }^{\mathrm{e}}$ & 30 & 45 & $i \mathrm{Pr}_{2} \mathrm{O}$ & 48 & 44 & 7 & 9 & 1 \\
\hline 13 & Lipase $A Y^{\mathrm{e}}$ & 30 & 45 & $i \mathrm{Pr}_{2} \mathrm{O}$ & 48 & 11 & 2 & 16 & 1 \\
\hline 14 & Lipase $\mathrm{AK}^{\mathrm{e}}$ & 30 & 45 & $i \mathrm{Pr}_{2} \mathrm{O}$ & 48 & 25 & 1 & 3 & 1 \\
\hline 15 & PPL & 30 & 45 & $i \mathrm{Pr}_{2} \mathrm{O}$ & 48 & 20 & 5 & 20 & 2 \\
\hline
\end{tabular}

On the basis of these preliminary results, preparative-scale resolutions of $\left(1 S^{*}, 2 R^{*}, 5 R^{*}\right)-( \pm)-4$, $\left(1 S^{*}, 2 S^{*}, 5 S^{*}\right)-( \pm)-5,\left(1 S^{*}, 2 S^{*}, 5 S^{*}\right)-( \pm)-6$ and $\left(1 S^{*}, 2 S^{*}, 5 R^{*}\right)-( \pm)-10$ were performed in $t$-BuOMe at $60{ }^{\circ} \mathrm{C}$ in the presence of CAL-B $\left(30 \mathrm{mg} \mathrm{mL}^{-1}\right)$ with 0.5 equiv. of $\mathrm{H}_{2} \mathrm{O}$. The results are summarized in Table 2 and the Experimental Section. It can be noted, that the hydroxy-substituted $\beta$-amino acid 
enantiomers (11-14) are missing from the Table, as above observed, the $\beta$-amino acid ethyl esters $(1 S, 2 S, 5 R)-4,(1 R, 2 R, 5 R)-5,(1 R, 2 R, 5 R)-6$ and $(1 R, 2 R, 5 S)-10$ underwent polymerization (the sideproduct(s) were not characterized). As it was confirmed for the product obtained from $(1 S, 2 S, 5 R)-4$, the mass spectrum shows two major peaks. The mass difference between these two peaks is $259.4 \mathrm{~m} / \mathrm{z}$. This corresponds to the mass of one Boc-protected saturated amino acid. Furthermore the MS/MS spectra of these two peaks show losses of Boc groups and Boc-protected saturated amino acid residues. These results suggest the polymerization of the amino acid derivative. A possible pathway is the enzyme catalyzed Michael addition. The NMR results support this view, because the signals of the protons of the double bonds and the $\mathrm{OH}$ groups are missing. Since CAL-B showed $S$-selectivity towards the earlier performed hydrolyses of $c i s$ and $R$-selectivity of trans carbocyclic $\beta$-amino esters [28], $S$-selectivity for hydrolysis of $\left(1 S^{*}, 2 R^{*}, 5 R^{*}\right)-( \pm)-4$ and $R$-selectivity for hydrolysis of $\left(1 S^{*}, 2 S^{*}, 5 S^{*}\right)-( \pm)-5,\left(1 S^{*}, 2 S^{*}, 5 S^{*}\right)-( \pm)-6$ and $\left(1 S^{*}, 2 S^{*}, 5 R^{*}\right)-( \pm)-10$ has been assumed. These lipasecatalysed reactions of hydroxy-substituted $\beta$-amino esters presumably proceeds in two stages: first, the Ser $\mathrm{OH}$ attacks the carbonyl group of ester function and forms the acyl-enzyme intermediate and second, deacylation of the enzyme in combination with side reactions (polymerization) results the products ( $\beta$-amino acid being one of them). Even though modelling has not been used, knowledge of the active site structure of CAL-B, together with the stereostructures of hydroxy-substituted $\beta$-amino esters (CS Chem 3D 6.0) and a consideration of the results obtained for the CAL-B-catalysed hydrolysis of ethyl cis-(2-aminocyclohex-3-ene)-1-carboxylate (Figure 1), can be utilized to predict the interaction between the substrate and the acyl binding site. Figures 2 and 3 illustrate the possible accommodations for the enantiomers in the apparent active site of CAL-B (only the Ser residue is indicated), which suggest the proposed selectivities, since the orientations $(1 R, 2 S, 5 S)-\mathbf{4},(1 S, 2 S, 5 S)-\mathbf{5}$, $(1 S, 2 S, 5 S)-\mathbf{6}$ and $(1 S, 2 S, 5 R)-\mathbf{1 0}$ do not appear to be appropriate to ensure Ser OH attack.

Figure 1. S-selective hydrolysis of ethyl cis-(2-aminocyclohex-3-ene)-1-carboxylate [28].
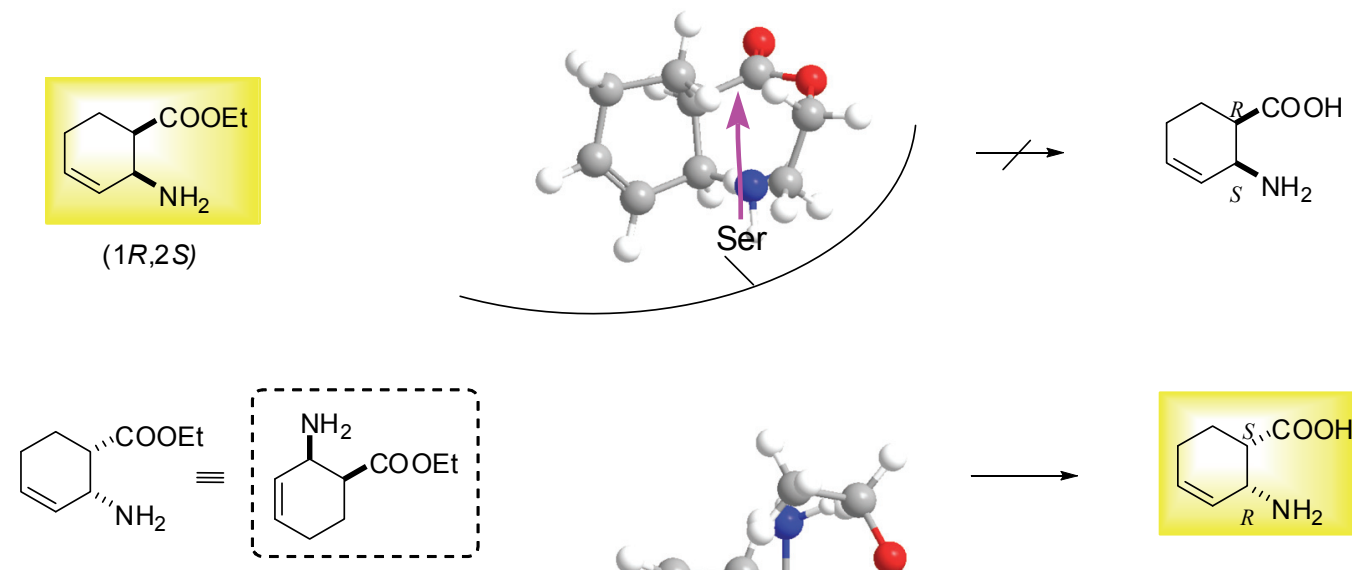

$(1 S, 2 R)$

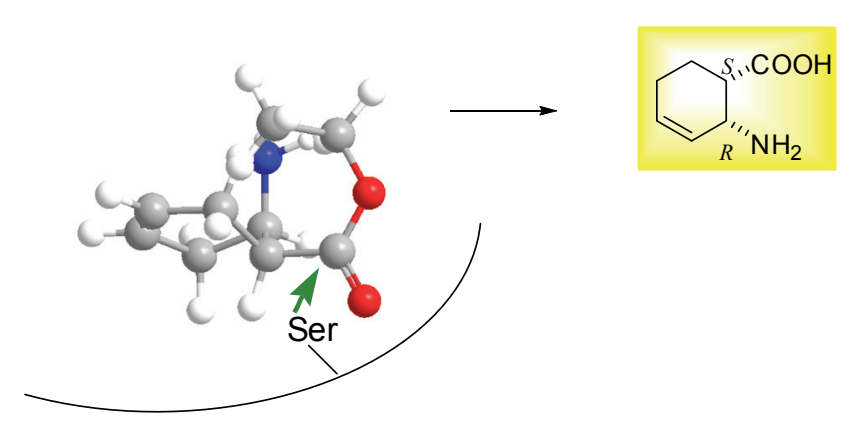


Figure 2. $S$-selective hydrolysis of $\left(1 S^{*}, 2 R^{*}, 5 R^{*}\right)-( \pm)-4$.

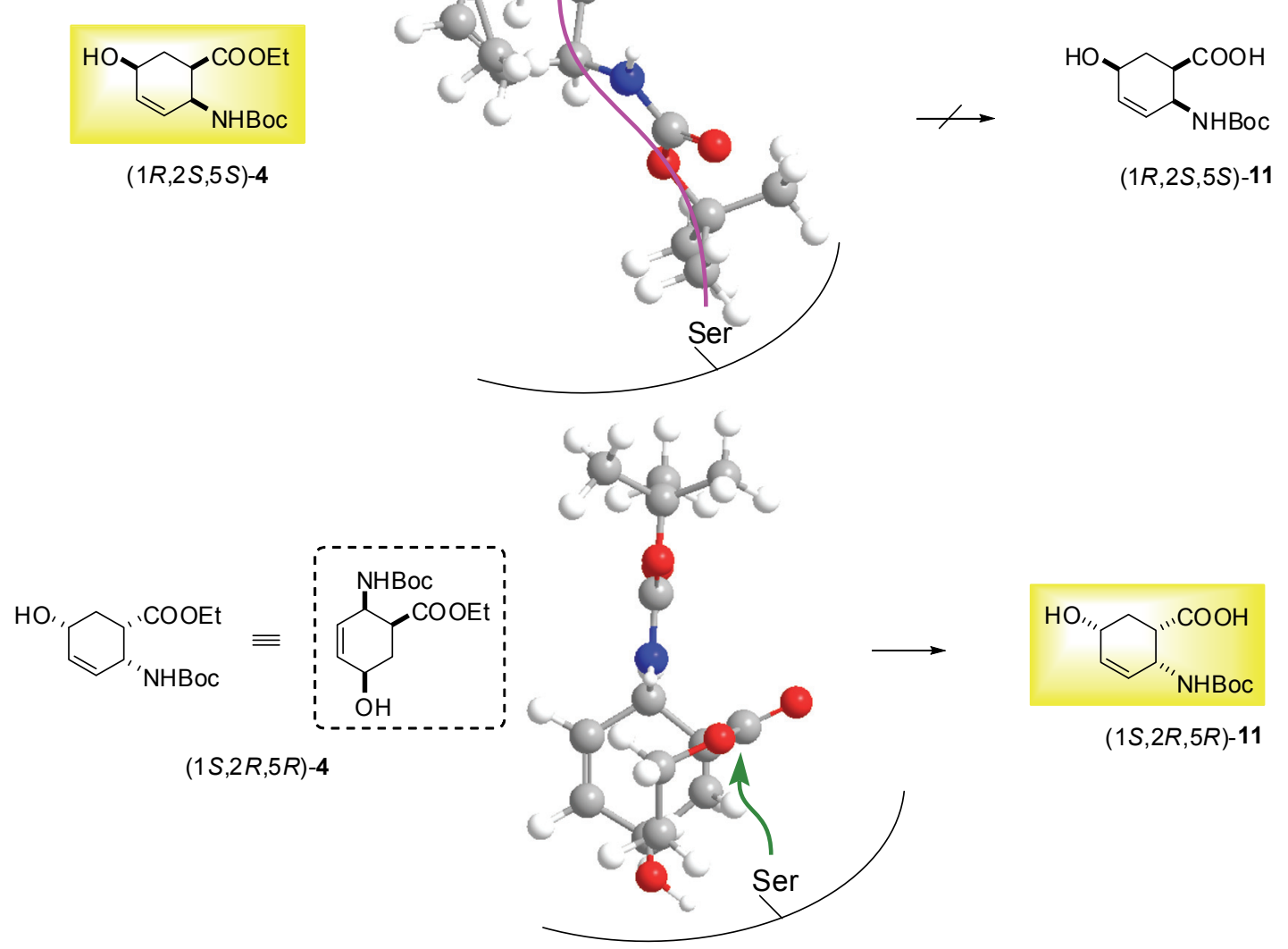

Figure 3. $R$-selective hydrolysis of $\left(1 S^{*}, 2 S^{*}, 5 S^{*}\right)-( \pm)-5, \quad\left(1 S^{*}, 2 S^{*}, 5 S^{*}\right)-( \pm)-6$ and $\left(1 S^{*}, 2 S^{*}, 5 R^{*}\right)-( \pm)-10$.

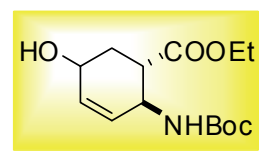

(1S,2S,5S)-5

(1S,2S,5S)-6

$(1 S, 2 S, 5 R)-10$

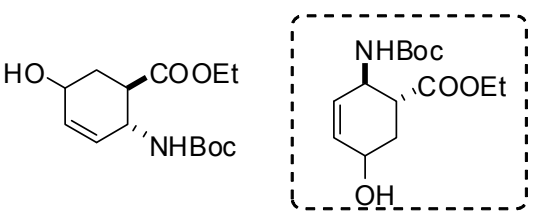

$(1 R, 2 R, 5 R)-5$

$(1 R, 2 R, 5 R)-6$

$(1 R, 2 R, 5 S)-10$
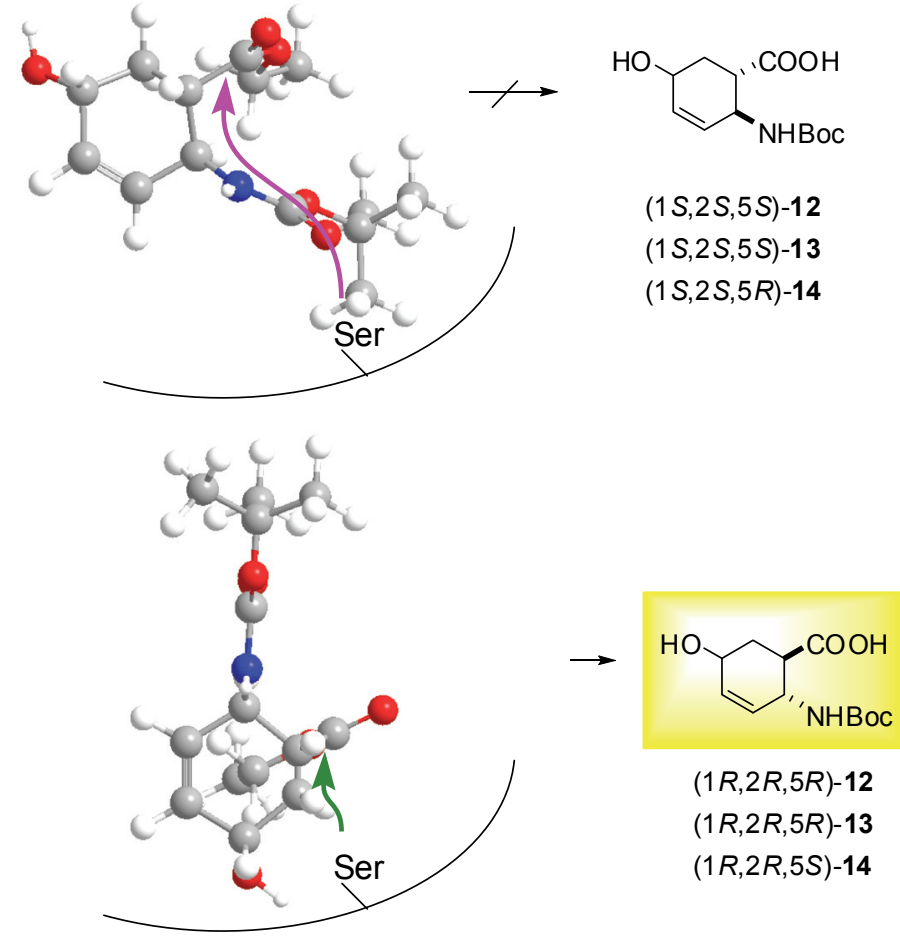
Table 2. Lipase-catalyzed preparative-scale hydrolyses of $\left(1 S^{*}, 2 R^{*}, 5 R^{*}\right)-( \pm)-4$, $\left(1 S^{*}, 2 S^{*}, 5 S^{*}\right)-( \pm)-5,\left(1 S^{*}, 2 S^{*}, 5 S^{*}\right)-( \pm)-6$ and $\left(1 S^{*}, 2 S^{*}, 5 R^{*}\right)-( \pm)-10^{\mathrm{a}}$.

\begin{tabular}{lcccccc}
\hline \multirow{2}{*}{ Racemate } & \multirow{2}{*}{ Time (days) } & \multirow{2}{*}{ Conv. $^{\mathbf{b}}(\mathbf{\%})$} & \multicolumn{4}{c}{ Unreacted enantiomer } \\
\cline { 5 - 8 } & & & Yield (\%) & Isomer & $\boldsymbol{e e}^{\mathbf{c}} \mathbf{( \% )}$ & {$[\boldsymbol{\alpha}]_{\mathbf{D}}{ }^{25}(\mathbf{E t O H})$} \\
\hline$\left(1 S^{*}, 2 R^{*}, 5 R^{*}\right)-( \pm)-\mathbf{4}$ & 10 & 43 & 32 & $(1 R, 2 S, 5 S)-\mathbf{4}$ & 68 & $+34(c 0.19)$ \\
$\left(1 S^{*}, 2 S^{*}, 5 S^{*}\right)-( \pm)-\mathbf{5}$ & 10 & 41 & 34 & $(1 S, 2 S, 5 S)-\mathbf{5}$ & 78 & $+16(c 0.165)$ \\
$\left(1 S^{*}, 2 S^{*}, 5 S^{*}\right)-( \pm)-\mathbf{6}$ & 10 & 36 & 29 & $(1 S, 2 S, 5 S)-\mathbf{6}$ & 54 & $-4(c 0.24)$ \\
$\left(1 S^{*}, 2 S^{*}, 5 R^{*}\right)-( \pm)-\mathbf{1 0}$ & 7 & 43 & 41 & $(1 S, 2 S, 5 R)-\mathbf{1 0}$ & 90 & $+100(c 0.155)$ \\
\hline
\end{tabular}

${ }^{\mathrm{a}} 0.5$ equiv. of $\mathrm{H}_{2} \mathrm{O} ; \mathrm{CAL}-\mathrm{B}\left(30 \mathrm{mg} \mathrm{mL}{ }^{-1}\right)$ in $t$-BuOMe at $60{ }^{\circ} \mathrm{C} ;{ }^{\mathrm{b}}$ Calculated using an internal standard ( $n$-heptadecane, GC); ${ }^{\mathrm{c}}$ According to GC or HPLC (Experimental Section).

\section{Experimental}

\subsection{Materials and methods}

CAL-B (lipase B from Candida antarctica, produced by the submerged fermentation of a genetically modified Aspergillus oryzae microorganism and adsorbed on a macroporous resin) and porcine pancreatic lipase (PPL) were from Sigma-Aldrich. CAL-A (lipase A from Candida antarctica) was purchased from Roche Diagnostics Corporation. Lipase PS-IM (immobilized on diatomaceous earth) and PS-SD (Burkholderia cepacia) were kind gifts from Amano Enzyme Europe Ltd. Lipase AK (Pseudomonas fluorescens) was from Amano Pharmaceuticals, and lipase AY (Candida rugosa) was from Fluka. All the chemicals were purchased from Aldrich or Fluka. The solvents were of the highest analytical grade. Melting points were determined with a Kofler apparatus. NMR spectra were recorded on a Bruker DRX 400 spectrometer. Chemical shifts are given in ppm relative to TMS as internal standard, with $\mathrm{CDCl}_{3}$ or DMSO as solvent. Optical rotations were measured with a PerkinElmer 341 polarimeter. The mass spectra were recorded on a Finnigan MAT 95S spectrometer. Elemental analyses were performed with a Perkin-Elmer CHNS-2400 Ser II Elemental Analyzer. Compounds $\left(1 R^{*}, 2 S^{*}\right)-( \pm)-\mathbf{1}$ and $\left(1 S^{*}, 2 S^{*}\right)-( \pm)-7$ were prepared according to our earlier method [32].

\subsection{Typical small-scale enzymatic experiment}

Racemic substrate $(0.05 \mathrm{M}$ solution) in an organic solvent $(1 \mathrm{~mL})$ was added to the lipase tested (30, 50 or $\left.75 \mathrm{mg} \mathrm{mL}^{-1}\right)$. Water ( 0.5 equiv.) was next added. The mixture was shaken at $40,50,60$ or 70 ${ }^{\circ} \mathrm{C}$. The progress of the reaction was followed by taking samples from the reaction mixture at intervals and analysing them by GC or HPLC. The ee values for the unreacted $\beta$-amino ester $(1 S, 2 S, 5 R)-\mathbf{1 0}$ and produced $\beta$-amino acid $(1 R, 2 R, 5 S)$-14 enantiomers were determined by using HPLC equipped with Chiralpak IA $5 \mu$ column $(0.4 \mathrm{~cm} \times 1 \mathrm{~cm})$, after derivatization $\left(\mathrm{Ac}_{2} \mathrm{O}\right.$ in the presence of 4-dimethylaminopyridine and pyridine) for $(1 S, 2 S, 5 R)-\mathbf{1 0}$ and double derivatization $\left(\mathrm{CH}_{2} \mathrm{~N}_{2}, \mathrm{Ac}_{2} \mathrm{O}\right.$ in the presence of 4-dimethylaminopyridine and pyridine) [33] for $(1 R, 2 R, 5 S)-\mathbf{1 4}$ [the mobile phase: $n$-hexane/2-propanol (90/10); flow rate $0.5 \mathrm{~mL} \mathrm{~min}^{-1}$; detection at $205 \mathrm{~nm}$; retention times (min); (1S,2S,5R)-10: 28.96 (antipode: 24.96); (1R,2R,5S)-14: 28,06 (antipode: 36.05)]. The ee values for $(1 R, 2 S, 5 S)-\mathbf{4},(1 S, 2 S, 5 S)-\mathbf{5},(1 S, 2 S, 5 S)-\mathbf{6},(1 S, 2 R, 5 R)-\mathbf{1 1},(1 R, 2 R, 5 R)-\mathbf{1 2}$ and $(1 R, 2 R, 5 R)-\mathbf{1 3}$, were determined by using GC equipped with Chromopack Chiralsil-Dex CB column $(25 \mathrm{~m})$ after derivatization with $\mathrm{CH}_{2} \mathrm{~N}_{2}$ [33] [190 ${ }^{\circ} \mathrm{C} ; 140 \mathrm{kPa}$; retention times (min): (1S,2S,5S)-5: 12.67 (antipode: 
13.28); (1R,2R,5R)-12: 11.80 (antipode: 11.30); (1S,2S,5S)-6: 13,29 (antipode: 14.51); (1R,2R,5R)-13: 12.87 (antipode: 12.38)], [170 ${ }^{\circ} \mathrm{C} ; 140 \mathrm{kPa}$; retention times (min): (1R,2S,5S)-4: 27.06 (antipode: 28.12); (1S,2R,5R)-11: 14.47 (antipode: 13.76)].

3.3. Synthesis of iodolactones tert-butyl $\left(1 R^{*}, 2 S^{*}, 4 S^{*}, 5 S^{*}\right)$-4-iodo-7-oxo-6-oxabicyclo[3.2.1]octan-2ylcarbamate $\left[\left(1 R^{*}, 2 S^{*}, 4 S^{*}, 5 S^{*}\right)-( \pm)-2\right]$ and tert-butyl $\left(1 S^{*}, 2 S^{*}, 4 R^{*}, 5 R^{*}\right)-4$-iodo-7-oxo-6-oxabicyclo-

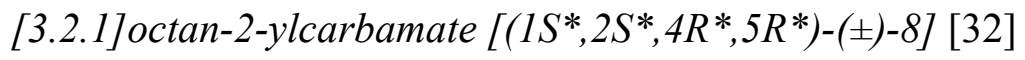

To a solution of $N$-Boc-protected amino acid [36 mmol $\left(1 R^{*}, 2 S^{*}\right)-( \pm)-1$ or $\left.\left(1 S^{*}, 2 S^{*}\right)-( \pm)-7\right]$ in $\mathrm{CH}_{2} \mathrm{Cl}_{2}(200 \mathrm{~mL}), \mathrm{KI}$ (5 equiv, $\left.180 \mathrm{mmol}\right), \mathrm{NaHCO}_{3}$ (4 equiv, $\left.144 \mathrm{mmol}\right), \mathrm{H}_{2} \mathrm{O}(200 \mathrm{~mL})$ and $\mathrm{I}_{2}(2.1$ equiv, $75 \mathrm{mmol}$ ) were added. After stirring for $12 \mathrm{~h}$ at room temperature, the mixture was taken up in $\mathrm{CH}_{2} \mathrm{Cl}_{2}(300 \mathrm{~mL})$, and washed with saturated aqueous $\mathrm{Na}_{2} \mathrm{SO}_{3}$ solution. The organic layer was then dried $\left(\mathrm{Na}_{2} \mathrm{SO}_{4}\right)$ and concentrated under reduced pressure and resulted $\left(1 R^{*}, 2 S^{*}, 4 S^{*}, 5 S^{*}\right)-( \pm)-2$ [white solid; yield: $75 \%$; mp $180-183{ }^{\circ} \mathrm{C}$ ( $n$-hexane); $\left(\mathrm{R}_{\mathrm{f}}=0.7, n\right.$-hexane-EtOAc $\left.\left.2: 1\right)\right]$ or $\left(1 S^{*}, 2 S^{*}, 4 R^{*}, 5 R^{*}\right)$ $( \pm)-8$ [white solid; yield: $83 \%$; mp $128-130{ }^{\circ} \mathrm{C}\left(n\right.$-hexane); $\left(\mathrm{R}_{\mathrm{f}}=0.65, n\right.$-hexane-EtOAc $\left.\left.2: 1\right)\right]$.

${ }^{1} \mathrm{H}-\mathrm{NMR}\left(400 \mathrm{MHz}, \mathrm{CDCl}_{3}\right)$ for $\left(1 R^{*}, 2 S^{*}, 4 S^{*}, 5 S^{*}\right)-( \pm)-2: \delta=1.48(\mathrm{~s}, 9 \mathrm{H}, t \mathrm{Bu}), 2.13-2.23(\mathrm{~m}, 1 \mathrm{H}$, $\left.\mathrm{CH}_{2}\right), 2.45-2.53\left(\mathrm{~m}, 2 \mathrm{H}, \mathrm{CH}_{2}\right), 2.79-2.90\left(\mathrm{~m}, 2 \mathrm{H}, \mathrm{H}-1\right.$ and $\left.\mathrm{CH}_{2}\right), 4.16-4.22(\mathrm{~m}, 1 \mathrm{H}, \mathrm{H}-4), 4.48-4.53$ (m, 1H, H-2), 4.78 (brs, $1 \mathrm{H}, \mathrm{N}-\mathrm{H}), 4.80-4.85$ (m, 1H, H-5); ${ }^{13} \mathrm{C}-\mathrm{NMR}\left(100 \mathrm{MHz}, \mathrm{CDCl}_{3}\right): \delta=20.8$, 28.7, 33.9, 36.9, 44.9, 46.1, 80.1, 82.0, 156.8, 172.0 .

${ }^{1} \mathrm{H}-\mathrm{NMR}\left(400 \mathrm{MHz}, \mathrm{CDCl}_{3}\right)$ for $\left(1 S^{*}, 2 S^{*}, 4 R^{*}, 5 R^{*}\right)-( \pm)-8: \delta=1.50(\mathrm{~s}, 9 \mathrm{H}, t \mathrm{Bu}), 2.23-2.30(\mathrm{~m}, 1 \mathrm{H}$, $\left.\mathrm{CH}_{2}\right), 2.33-2.43\left(\mathrm{~m}, 1 \mathrm{H}, \mathrm{CH}_{2}\right), 2.87-3.07$ (m, 3H, H-1 and $\left.\mathrm{CH}_{2}\right), 4.22-4.25(\mathrm{~m}, 1 \mathrm{H}, \mathrm{H}-4), 4.38-4.43$ (m, 1H, H-2), 4.88-4.93 (m, 1H, H-5), 5.38 (brs, $1 \mathrm{H}, \mathrm{N}-\mathrm{H}) ;{ }^{13} \mathrm{C}-\mathrm{NMR}\left(100 \mathrm{MHz}, \mathrm{CDCl}_{3}\right): \delta=20.1$, 28.5, 29.1, 33.9, 43.0, 46.6, 79.4, 81.7, 177.0, 179.0.

3.4. Dehydroiodination reactions to obtain tert-butyl $\left(1 R^{*}, 2 S^{*}, 5 S^{*}\right)-7-o x o-6-$ oxabicyclo[3.2.1]oct-3-

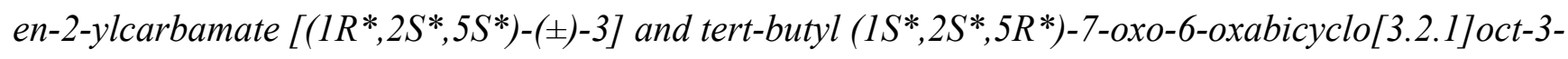
en-2-ylcarbamate $\left[\left(1 S^{*}, 2 S^{*}, 5 R^{*}\right)-( \pm)-9\right]$

To a solution of iodolactone [12 mmol $\left(1 R^{*}, 2 S^{*}, 4 S^{*}, 5 S^{*}\right)-( \pm)-2$ or $\left.\left(1 S^{*}, 2 S^{*}, 4 R^{*}, 5 R^{*}\right)-( \pm)-8\right]$ in THF $(60 \mathrm{~mL})$ DBU (2.1 equiv, $25.2 \mathrm{mmol}$ ) was added and the mixture was stirred at $65{ }^{\circ} \mathrm{C}$ for $4 \mathrm{~h}$. Then the solution was concentrated under reduced pressure and the residue was taken up in EtOAc $(140 \mathrm{~mL})$. The organic layer was washed with $\mathrm{H}_{2} \mathrm{O}(3 \times 70 \mathrm{~mL})$, dried $\left(\mathrm{Na}_{2} \mathrm{SO}_{4}\right)$ and concentrated under vacuum. The residue was crystallized from $n$-hexane-EtOAc and resulted $\left(1 R^{*}, 2 S^{*}, 5 S^{*}\right)-( \pm)-3$ [white solid; yield: $72 \%$; mp $148-149{ }^{\circ} \mathrm{C}$ (n-hexane-EtOAc); $\left(\mathrm{R}_{\mathrm{f}}=0.6, n\right.$-hexane-EtOAc $\left.2: 1\right)$ ] or $\left(1 S^{*}, 2 S^{*}, 5 R^{*}\right)-( \pm)-9$ [white solid; yield: $71 \%$; mp 149-151 ${ }^{\circ} \mathrm{C}$ ( $n$-hexane); $\left(\mathrm{R}_{\mathrm{f}}=0.6, n\right.$-hexane-EtOAc $2: 1)]$.

${ }^{1} \mathrm{H}-\mathrm{NMR}\left(400 \mathrm{MHz}, \mathrm{CDCl}_{3}\right)$ for $\left(1 R^{*}, 2 S^{*}, 5 S^{*}\right)-( \pm)-3: \delta=1.48(\mathrm{~s}, 9 \mathrm{H}, t \mathrm{Bu}), 2.16-2.22\left(\mathrm{~m}, 1 \mathrm{H}, \mathrm{CH}_{2}\right)$, 2.54-2.63 (m, 1H, CH $), 3.01-3.06(\mathrm{~m}, 1 \mathrm{H}, \mathrm{H}-1), 4.66-4.72(\mathrm{~m}, 1 \mathrm{H}, \mathrm{H}-2), 4.48-4.53$ (m, 1H, H-2), 4.81-4.85 (m, 1H-5), 4.90 (brs, 1H, N-H), 5.78-5.82 (m, 1H, H-3), 6.30-6.37 (m, 1H, H-4); ${ }^{13} \mathrm{C}-\mathrm{NMR}$ $\left(100 \mathrm{MHz}, \mathrm{CDCl}_{3}\right): \delta=28.7,37.1,44.1,48.9,73.5,80.6,131.1,132.1,158.8,172.4$. 
${ }^{1} \mathrm{H}-\mathrm{NMR}(400 \mathrm{MHz}, \mathrm{DMSO})$ for $\left(1 S^{*}, 2 S^{*}, 5 R^{*}\right)-( \pm)-9: \delta=1.42(\mathrm{~s}, 9 \mathrm{H}, t \mathrm{Bu}), 2.28-2.36\left(\mathrm{~m}, 2 \mathrm{H}, \mathrm{CH}_{2}\right)$, 2.69-2.75 (m, 1H, H-1), 4.20-4.28 (m, 1H, H-2), 4.71-4.76 (m, 1H, H-5), 5.59-5.65 (m, 1H, H-3), 6.40-6.46 (m, 1H, H-4), 7.48 (brs, 1H, N-H). ${ }^{13} \mathrm{C}-\mathrm{NMR}$ (100 MHz, DMSO): 29.1, 31.5, 44.4, 47.6, $73.9,79.4,131.1,132.9,155.7,178.2$.

3.5. Lactone ring opening reaction to obtain ethyl $\left(1 R^{*}, 2 S^{*}, 5 S^{*}\right)$-2-(tert-butoxycarbonylamino)-5hydroxycyclohex-3-enecarboxylate $\left[\left(1 R^{*}, 2 S^{*}, 5 S^{*}\right)-( \pm)-4\right]$, ethyl $\left(1 S^{*}, 2 S^{*}, 5 S^{*}\right)-2-($ tert-butoxycarbonyl-

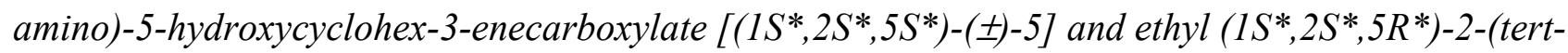
butoxycarbonylamino)-5-hydroxycyclohex-3-enecarboxylate [(1 $\left.\left.S^{*}, 2 S^{*}, 5 R^{*}\right)-( \pm)-10\right]$

To a solution of unsaturated lactone [4 mmol of $\left(1 R^{*}, 2 S^{*}, 5 S^{*}\right)-( \pm)-3$ or $\left.\left.\left(1 S^{*}, 2 S^{*}, 5 R^{*}\right)-( \pm)-9\right)\right]$ in anhydrous EtOH $(20 \mathrm{~mL}) \mathrm{NaOEt}(1.2$ equiv, $4.8 \mathrm{mmol})$ was added at $0{ }^{\circ} \mathrm{C}$ and the reaction mixture was further stirred at the temperature and time indicated. Then the EtOH was removed under reduced pressure at $40{ }^{\circ} \mathrm{C}$ and the residue was taken up in EtOAc $(50 \mathrm{~mL})$. The organic layer was washed with $\mathrm{H}_{2} \mathrm{O}(3 \times 25 \mathrm{~mL})$, dried $\left(\mathrm{Na}_{2} \mathrm{SO}_{4}\right)$ and concentrated under reduced pressure. The crude residue was crystallized from $n$-hexane-EtOAc to give the desired product:

$\left(1 R^{*}, 2 S^{*}, 5 S^{*}\right)-( \pm)-4$ : white solid; yield: $67 \%$; mp $88-90{ }^{\circ} \mathrm{C}\left(n\right.$-hexane-EtOAc); $\left(\mathrm{R}_{\mathrm{f}}=0.4, n\right.$-hexaneEtOAc 1:1). ${ }^{1} \mathrm{H}-\mathrm{NMR}\left(400 \mathrm{MHz}, \mathrm{CDCl}_{3}\right): \delta=1.26\left(\mathrm{t}, 3 \mathrm{H}, \mathrm{CH}_{3}\right), 1.42(\mathrm{~s}, 9 \mathrm{H}, t \mathrm{Bu}), 1.88-1.65(\mathrm{~m}, 1 \mathrm{H}$, $\left.\mathrm{CH}_{2}\right), 2.09-2.17\left(\mathrm{~m}, 1 \mathrm{H}, \mathrm{CH}_{2}\right), 2.84-2.91(\mathrm{~m}, 1 \mathrm{H}, \mathrm{H}-1), 4.08-4.18\left(\mathrm{~m}, 3 \mathrm{H}, \mathrm{OCH}_{2}\right.$ and $\left.\mathrm{H}-2\right), 4.46-4.50$ (m, 1H, H-5), 4.90 (brs, 1H, N-H), 5.67-5.71 (m, 1H, H-3), 5.82-5.88 (m, 1H, H-4); ${ }^{13} \mathrm{C}-\mathrm{NMR}$ $\left(100 \mathrm{MHz}, \mathrm{CDCl}_{3}\right): \delta=14.8,29.0,29.7,42.9,45.8,61.6,66.2,78.6,126.9,125.9,155.6,172.8$.

$\left(1 S^{*}, 2 S^{*}, 5 S^{*}\right)-( \pm)-5:$ white solid; yield: $78 \%$; mp 107-108 ${ }^{\circ} \mathrm{C}$ ( $n$-hexane-EtOAc); $\left(\mathrm{R}_{\mathrm{f}}=0.35, n\right.$ hexane-EtOAc 1:1). ${ }^{1} \mathrm{H}-\mathrm{NMR}(400 \mathrm{MHz}, \mathrm{DMSO}): \delta=1.18\left(\mathrm{t}, 3 \mathrm{H}, \mathrm{CH}_{3}\right), 1.37(\mathrm{~s}, 9 \mathrm{H}, t \mathrm{Bu}), 1.72-1.80$ (m, 2H, $\mathrm{CH}_{2}$ ), 2.67-2.70 (m, 1H, H-1), 4.00-4.15 (m, 4H, $\mathrm{OCH}_{2}, \mathrm{H}-2$ and H-5), 4.86 (brs, 1H, O-H), 5.46-5.52 (m, 1H, H-3), 5.68-5.73 (m, 1H, H-4), 6.68 (brs, $1 \mathrm{H}, \mathrm{N}-\mathrm{H}) ;{ }^{13} \mathrm{C}-\mathrm{NMR}$ (100 MHz, DMSO): $\delta=14.8,29.1,34.3,41.8,49.3,60.8,61.6,78.6,131.0,131.4,156.0,174.6$.

$\left(1 S^{*}, 2 S^{*}, 5 R^{*}\right)-( \pm)-10$ : white solid; yield: $64 \%$; mp $130-133{ }^{\circ} \mathrm{C}$ (n-hexane-EtOAc); $\left(\mathrm{R}_{\mathrm{f}}=0.4, n\right.$ hexane-EtOAc 1:1). ${ }^{1} \mathrm{H}-\mathrm{NMR}(400 \mathrm{MHz}, \mathrm{DMSO}): \delta=1.17\left(\mathrm{t}, 3 \mathrm{H}, \mathrm{CH}_{3}, J=7.15 \mathrm{~Hz}\right), 1.36$ (s, 9H, $t \mathrm{Bu}), 1.46-1.53\left(\mathrm{~m}, 1 \mathrm{H}, \mathrm{CH}_{2}\right), 1.97-2.07\left(\mathrm{~m}, 1 \mathrm{H}, \mathrm{CH}_{2}\right), 3.96-4.11\left(\mathrm{~m}, 3 \mathrm{H}, \mathrm{OCH}_{2}\right.$ and $\left.\mathrm{H}-2\right), 4.18-4.25$ (m, 1H, H-5), 4.90 (brs, 1H, O-H), 5.35-5.40 (m, 1H, H-3), 5.59-5.63 (m, 1H, H-4), 6.93 (brs, 1H, N$\mathrm{H}) ;{ }^{13} \mathrm{C}-\mathrm{NMR}(100 \mathrm{MHz}, \mathrm{DMSO}): \delta=14.9,29.1,36.1,45.9,49.6,60.9,65.6,78.6,129.9,134.3$, 155.9, 173.8 .

\subsection{Preparation of ethyl $\left(1 S^{*}, 2 S^{*}, 5 S^{*}\right)-2-($ tert-butoxycarbonylamino)-5-hydroxycyclohexane-} carboxylate $\left[\left(1 S^{*}, 2 S^{*}, 5 S^{*}\right)-( \pm)-6\right]$

A solution of $\left(1 S^{*}, 2 S^{*}, 5 S^{*}\right)-( \pm)-5(200 \mathrm{mg}), 10 \% \mathrm{Pd} / \mathrm{C}(40 \mathrm{mg})$ in EtOAc $(15 \mathrm{~mL})$ was stirred under $\mathrm{H}_{2}$ atmosphere at room temperature for $2 \mathrm{~h}$. Then the Pd was filtered off through Celite and the filtrate was concentrated under reduced pressure. The crude product was purified on column chromatography on silica gel ( $n$-hexane-EtOAc $1: 1)$ and resulted $\left(1 S^{*}, 2 S^{*}, 5 S^{*}\right)-( \pm)-6$ as a colourless oil; yield: $89 \%$; 
$\left(\mathrm{R}_{\mathrm{f}}=0.4, n\right.$-hexane-EtOAc 1:1). ${ }^{1} \mathrm{H}-\mathrm{NMR}\left(400 \mathrm{MHz}, \mathrm{CDCl}_{3}\right): \delta=1.24\left(\mathrm{t}, 3 \mathrm{H}, \mathrm{CH}_{3}, J=7.10 \mathrm{~Hz}\right), 1.42$ $(\mathrm{s}, 9 \mathrm{H}, t \mathrm{Bu}), 1.57-2.00\left(\mathrm{~m}, 6 \mathrm{H}, \mathrm{CH}_{2}, 2.68-2.79(\mathrm{~m}, 1 \mathrm{H}, \mathrm{H}-1), 3.68-3.80\right.$ (m, 1H, H-2), 4.07-4.20 (m, $3 \mathrm{H}, \mathrm{OCH}_{2}$ and $\left.\mathrm{H}-5\right), 4.61$ (brs, $\left.1 \mathrm{H}, \mathrm{N}-\mathrm{H}\right) .{ }^{13} \mathrm{C}-\mathrm{NMR}\left(100 \mathrm{MHz}, \mathrm{CDCl}_{3}\right): \delta=14.6,27.2,28.7,31.6$, $35.1,44.6,50.9,61.0,65.0,79.7,155.4,174.3$.

\subsection{Preparative-scale resolution of $\left(1 R^{*}, 2 S^{*}, 5 S^{*}\right)-( \pm)-4$}

Compound (1 $\left.R^{*}, 2 S^{*}, 5 S^{*}\right)-( \pm)-4(200 \mathrm{mg}, 0.70 \mathrm{mmol})$ was dissolved in $t$-BuOMe $(40 \mathrm{~mL})$. CAL-B $\left(1 \mathrm{~g}, 25 \mathrm{mg} \mathrm{mL}^{-1}\right)$ and $\mathrm{H}_{2} \mathrm{O}(6.3 \mu \mathrm{L}, 0.35 \mathrm{mmol})$ were added and the mixture was shaken in an incubator shaker at $60{ }^{\circ} \mathrm{C}$ for 10 days. The reaction was stopped by filtering off the enzyme at $43 \%$ conversion. The solvent was evaporated off, and the residue purified by column chromatography $(n-$ hexane:EtOAc 1:3); $\left(\mathrm{R}_{\mathrm{f}}=0.6, n\right.$-hexane-EtOAc $\left.1: 3\right)$ to give $(1 R, 2 S, 5 S)-\mathbf{4}\left[68 \mathrm{mg}, 32 \% ;[\alpha]_{\mathrm{D}}{ }^{25}=+34\right.$ (c 0.19 EtOH); m.p. $69-71{ }^{\circ} \mathrm{C}$; ee $=74 \%$ ]. The filtered-off enzyme was washed with distilled $\mathrm{H}_{2} \mathrm{O}(3 \mathrm{x}$ $15 \mathrm{~mL})$, than with $\mathrm{MeOH}(3 \times 15 \mathrm{~mL})$ and the combined solvents was evaporated off, yielding the mixture of mainly polymeric products and amino acid. ${ }^{1} \mathrm{H}-\mathrm{NMR}\left(400 \mathrm{MHz}, \mathrm{CDCl}_{3}, 25{ }^{\circ} \mathrm{C}\right.$, TMS) data for $(1 R, 2 S, 5 S)-\mathbf{4}$ were similar to those for $\left(1 R^{*}, 2 S^{*}, 5 S^{*}\right)-( \pm)-\mathbf{4}$. Analysis: calculated for $\mathrm{C}_{14} \mathrm{H}_{23} \mathrm{NO}_{5}$ (285.34): C, 58.93; H, 8.12; N, 4.91; found: C, 58.80; H, 8.08; N, 4.92.

\subsection{Preparative-scale resolution of $\left(1 S^{*}, 2 S^{*}, 5 S^{*}\right)-( \pm)-5$}

Following the procedure described above, the reaction of racemic $\left(1 S^{*}, 2 S^{*}, 5 S^{*}\right)-( \pm)-5(200 \mathrm{mg}$, $0.70 \mathrm{mmol})$ and $\mathrm{H}_{2} \mathrm{O}(6.3 \mu \mathrm{L}, 0.35 \mathrm{mmol})$ in $t$-BuOMe $(40 \mathrm{~mL})$ on the presence of CAL-B $(1 \mathrm{~g}$, $\left.25 \mathrm{mg} \mathrm{mL}^{-1}\right)$ at $60{ }^{\circ} \mathrm{C}$ afforded after 10 days $(1 S, 2 S, 5 S)-5\left[64 \mathrm{mg}, 32 \%\right.$; $[\alpha]_{\mathrm{D}}{ }^{25}=+16(c 0.165 \mathrm{EtOH})$; m.p. $100-102{ }^{\circ} \mathrm{C}$; ee $=78 \%$ ]. ${ }^{1} \mathrm{H}-\mathrm{NMR}\left(400 \mathrm{MHz}, \mathrm{CDCl}_{3}, 25{ }^{\circ} \mathrm{C}\right.$, TMS) data for $(1 S, 2 S, 5 S)-5$ were similar to those for $\left(1 S^{*}, 2 S^{*}, 5 S^{*}\right)-( \pm)-5$. Analysis: calculated for $\mathrm{C}_{14} \mathrm{H}_{23} \mathrm{NO}_{5}$ (285.34): C, 58.93; $\mathrm{H}$, 8.12; N, 4.91; found: C, 58.80; H, 8.08; N, 4.92 .

\subsection{Preparative-scale resolution of $\left(1 S^{*}, 2 S^{*}, 5 S^{*}\right)-( \pm)-6$}

Following the procedure described above, the reaction of racemic $\left(1 S^{*}, 2 S^{*}, 5 S^{*}\right)-( \pm)-6(200 \mathrm{mg}$, $0.69 \mathrm{mmol})$ and $\mathrm{H}_{2} \mathrm{O}(6.3 \mu \mathrm{L}, 0.35 \mathrm{mmol})$ in $t$-BuOMe $(40 \mathrm{~mL})$ on the presence of CAL-B $(1 \mathrm{~g}, 25$ $\left.\mathrm{mg} \mathrm{mL}{ }^{-1}\right)$ at $60{ }^{\circ} \mathrm{C}$ afforded after 10 days $(1 S, 2 S, 5 S)-6\left[58 \mathrm{mg}, 29 \% ;[\alpha]_{\mathrm{D}}{ }^{25}=-4(c 0.24 \mathrm{EtOH})\right.$; yellowish oil; $e e=54 \%$ ]. ${ }^{1} \mathrm{H}-\mathrm{NMR}\left(400 \mathrm{MHz}, \mathrm{CDCl}_{3}, 25^{\circ} \mathrm{C}\right.$, TMS) data for $(1 S, 2 S, 5 S)$-6 were similar to those for $\left(1 S^{*}, 2 S^{*}, 5 S^{*}\right)-( \pm)-6$. Analysis: calculated for $\mathrm{C}_{14} \mathrm{H}_{25} \mathrm{NO}_{5}(287.35)$ : C, 58.52; H, 8.77; N, 4.87; found: C, 58.66; H, 8.62; N, 4.85 .

\subsection{Preparative-scale resolution of $\left(1 S^{*}, 2 S^{*}, 5 R^{*}\right)-( \pm)-\mathbf{1 0}$}

Following the procedure described above, the reaction of racemic $\left(1 S^{*}, 2 S^{*}, 5 R^{*}\right)-( \pm)-10(200 \mathrm{mg}$, $0.70 \mathrm{mmol})$ and $\mathrm{H}_{2} \mathrm{O}(6.3 \mu \mathrm{L}, 0.35 \mathrm{mmol})$ in $t$-BuOMe $(40 \mathrm{~mL})$ on the presence of CAL-B $(1 \mathrm{~g}$, $\left.25 \mathrm{mg} \mathrm{mL}^{-1}\right)$ at $60{ }^{\circ} \mathrm{C}$ afforded after 7 days $(1 S, 2 S, 5 R)-10\left[97 \mathrm{mg}, 0.48 \% ;[\alpha]_{\mathrm{D}}{ }^{25}=+100(c 0.18\right.$ EtOH); m.p. $142-144{ }^{\circ} \mathrm{C}$; ee $=90 \%$ ]. ${ }^{1} \mathrm{H}-\mathrm{NMR}\left(400 \mathrm{MHz}, \mathrm{CDCl}_{3}, 25{ }^{\circ} \mathrm{C}\right.$, TMS $)$ data for $(1 R, 2 R, 5 R)-5$ were similar to those for $\left(1 S^{*}, 2 S^{*}, 5 S^{*}\right)-( \pm)-5 .{ }^{1} \mathrm{H}-\mathrm{NMR}\left(400 \mathrm{MHz}, \mathrm{CDCl}_{3}, 25{ }^{\circ} \mathrm{C}\right.$, TMS) data for 
$(1 S, 2 S, 5 R)-10$ were similar to those for $\left(1 S^{*}, 2 S^{*}, 5 R^{*}\right)-( \pm)-10$. Analysis: calculated for $\mathrm{C}_{14} \mathrm{H}_{23} \mathrm{NO}_{5}$ (285.34): C, 58.93; H, 8.12; N, 4.91; found: C, 58.91; H, 8.00; N, 4.97.

\section{Conclusions}

Four hydroxy-substituted $\beta$-amino ester stereoisomers were resolved through a simple direct enzymatic method, involving CAL-B-catalyzed enantioselective hydrolysis in organic media. Moderate to good enantiomeric excess values $(e e \geq 52 \%)$ were obtained for the unreacted amino esters when the reactions were performed with 0.5 equiv. of added $\mathrm{H}_{2} \mathrm{O}$, in $t$-BuOMe, at $60{ }^{\circ} \mathrm{C}$. Due to polymerization, the supposed $\beta$-amino acid enantiomers practically could not be isolated.

\section{Acknowledgements}

The authors are grateful to the Hungarian Research Foundation (OTKA No K 71938 and NK 81371) for financial support and for the award of Bolyai János Fellowship to Enikő Forró and Loránd Kiss. Thanks are due to Mr. István Mándity for his MS measurements. We are also indebted to Consejo Nacional de Ciencia y Tecnología (Conacyt-México) for financial support via Grants 60366 and J000.052 (México-Hungary Program, NKTH).

\section{References and Notes}

1. Fülöp, F. The chemistry of 2-aminocycloalkanecarboxylic acids. Chem. Rev. 2001, 101, 2181-2204.

2. Kiss, L.; Forró, E.; Fülöp, F. Amino Acids, Peptides and Proteins in Organic Chemistry; Hughes, A.B., Ed.; Wiley-VCH: Weinheim, Germany, 2009; Volume 1, pp. 367-409.

3. Zegarac, M.; Mestrovic, E.; Hulita, N.K.; Filic, D.; Dumic, M.; Grunenberg, A.; Keil, B.; Ceric, $\mathrm{H}$. Solid state forms of (-)-(1R,2S)-2-amino-4-methylenecyclopentanecarboxylic acid. PCT Int. Appl. WO 2005100302 A1, 2005.

4. Hameršak, Z.; Roje, M.; Avdagić, A.; Šunjić, V. Quinine-mediated parallel kinetic resolution of racemic cyclic anhydride: Stereoselective synthesis, relative and absolute configuration of novel alicyclic $\beta$-amino acids. Tetrahedron Asymmetr. 2007, 18, 635-644.

5. Steer, D.L.; Lew, R.A.; Perlmutter, P.; Smith, A.I.; Aguilar, M.I. $\beta$-Amino Acids. Versatile peptidomimetics. Curr. Med. Chem. 2002, 9, 811-822.

6. Martinek, T.A.; Mándity, I.M.; Fülöp, L.; Tóth, G.K.; Vass, E.; Hollósi, M.; Forró, E.; Fülöp, F. Effects of the alternating backbone configuration on the secondary structure and self-assembly of $\beta$-peptides. J. Am. Chem. Soc. 2006, 128, 13539-13544.

7. Price, J.L.; Horne, W.S.; Gellman, S.H. Discrete heterogeneous quaternary structure formed by $\alpha / \beta$-peptide foldamers and $\alpha$-peptides. J. Am. Chem. Soc. 2007, 129, 6376-6377.

8. Mándity, I.M.; Wéber, E.; Martinek, T.A.; Olajos, G.; Tóth, G.K.; Vass, E.; Fülöp, F. Design of peptidic foldamer helices: A stereochemical patterning approach. Angew. Chem. Int. Ed. 2009, 48, 2171-2175. 
9. Fernández, D.; Torres, E.; Avilés, F.X.; Ortuňo, R.M.; Vendrell, J. Cyclobutane-containing peptides: Evaluation as novel metallocarboxypeptidase inhibitors and modelling of their mode of action. Bioorg. Med. Chem. 2009, 17, 3824-3828.

10. Kapferer, P.; Vasella, A. Electrophilic bromination of N-acylated cyclohex-3-en-1-amines: Synthesis of 7-azanorbornanes. Helv. Chim. Acta 2004, 87, 2764-2789.

11. Carter, P.H. Process for preparation of diprotected 3-(4-fluorobenzyl)-1-(2,5-diaminocyclohexyl)piperidine via reductive amination. U.S. Pat. Appl. 2005/277,666, 2005; [Chem. Abstr. 2005, 144, 51452].

12. Fülöp, F.; Miklós, F.; Forró, E. Diexo-3-aminonorbornane-2-carboxylic acid as highly applicable chiral source for the enantioselective synthesis of heterocycles. Synlett 2008, 1687-1689.

13. Kiss, L.; Nonn, M.; Forró, E.; Sillanpää, R.; Fülöp, F. Synthesis of novel isoxazoline-fused cispentacin stereoisomers. Tetrahedron Lett. 2009, 50, 2605-2608.

14. Gedey, S.; Van der Eycken, J.; Fülöp, F. Synthesis of alicyclic $\beta$-lactams via the Ugi reaction on a solid support. Lett. Org. Chem. 2004, 1, 215-217.

15. Kanizsai, I.; Gyónfalvi, S.; Szakonyi; Z.; Sillanpää, R.; Fülöp, F. Synthesis of bi- and tricyclic $\beta$-lactam libraries in aqueous medium. Green Chem. 2007, 9, 357-360.

16. Kiss, L.; Forró, E.; Sillanpää, R.; Fülöp, F. Diastereo- and enantioselective synthesis of orthogonally protected 2,4-diaminocyclopentanecarboxylates: a flip from $\beta$-amino- to $\beta, \gamma$ diaminocarboxylates. J. Org. Chem. 2007, 72, 8786-8790.

17. Juaristi, E.; Soloshonok, V.A. Enantioselective synthesis of $\beta$-amino acids, 2 nd ed.; WileyInterscience: New York, NY, USA, 2005.

18. Mowery, B.P.; Lee, S.E.; Kissounko, D.A.; Epand, R.F.; Epand, R.M.; Weisblum, B.; Stahl, S.S.; Gellman, S.H. Mimicry of antimicrobial host-defense peptides by random copolymers. J. Am. Chem. Soc. 2007, 129, 15474-15476.

19. Juaristi, E.; Lopez-Ruiz, H. Recent advances in the enantioselective synthesis of beta-amino acids. Curr. Med. Chem. 1999, 6, 983-1004.

20 Palkó, M.; Kiss, L.; Fülöp, F. Syntheses of hydroxylated cyclic $\beta$-amino acids and derivatives. Curr. Med. Chem. 2005, 12, 3063-3083.

21. Kingston D.G.I.; Newman D.J. Taxoids: Cancer-fighting compounds from nature. Curr. Opin. Drug Disc. Dev. 2007, 10, 130-144.

22. Bunnage, M.E.; Ganesh, T.; Masesane, I.B.; Orton, D.; Steel, P.G. Asymmetric Synthesis of the Putative Structure of (-)-Oryzoxymycin. Org. Lett. 2003, 5, 239-242.

23. Ichikawa, Y.; Ohbayashi, M.; Hirata, K.; Nishizawa, R.; Isobe, M. Synthesis of Blastidic acid and Cytosinine, two components of Blasticidin S. Synlett 2001, 1763-1766.

24. Kiss, L.; Forró, E.; Fülöp, F. A new strategy for the regio- and stereoselective hydroxylation of trans-2-aminocyclohexenecarboxylic acid. Tetrahedron Lett. 2006, 47, 2855-2858.

25. Kiss, L.; Forró, E.; Sillanpää, R.; Fülöp, F. Novel functionalized cispentacin derivatives. Synthesis of 1,2,3-triazole-substituted 2-aminocyclopentanecarboxylate stereoisomers. Tetrahedron Asymmetr. 2008, 19, 2856-2860.

26. Benedek, G.; Palkó, M.; Wéber; E.; Martinek, T.A.; Forró, E.; Fülöp, F. Efficient synthesis of 3,4and 4,5-dihydroxy-2-aminocyclohexanecarboxylic acid enantiomers. Tetrahedron Asymmetr. 2009, 20, 2220-2225. 
27. Kiss, L.; Fülöp, F. Selective Syntheses of Functionalized Cyclic $\beta$-Amino Acids via Transformation of the Ring C-C Double Bonds. Synlett 2010, 1302-1314.

28. Forró E.; Fülöp F. The first direct enzymatic hydrolysis of alicyclic $\beta$-amino esters: -a route to enantiopure cis and trans $\beta$-amino acids. Chem. Eur. J. 2007, 13, 6397-6401.

29. Tasnádi G.; Forró E.; Fülöp F. An efficient new enzymatic method for the preparation of $\beta$-aryl- $\beta$ amino acid enantiomers. Tetrahedron Asymmetr. 2008, 19, 2072-2077.

30. Tasnádi G.; Forró E.; Fülöp F. Burkholderia cepacia lipase is an excellent enzyme for the enantioselective hydrolysis of $\beta$-heteroaryl- $\beta$-amino esters. Tetrahedron Asymmetr. 2009, 15, 1771-1777.

31. Tasnádi G.; Forró E.; Fülöp F. An improved enzymatic method for the preparation of valuable $\beta$-arylalkyl-substituted $\beta$-amino acid enantiomers. Org. Biomol. Chem. 2010, 8, 886-895.

32. Fülöp, F.; Palkó, M.; Forró, E.; Dervarics, M.; Martinek, T.A.; Sillanpää, R. Facile regio- and diastereoselective syntheses of hydroxylated 2-aminocyclohexanecarboxylic acids. Eur. J. Org. Chem. 2005, 3214-3220.

33. Forró, E. New gas chromatographic method for the enantioseparation of $\beta$-amino acids by a quick double-derivatization technique. J. Chromatogr. A 2009, 1216, 1025-1029.

Sample Availability: Samples of the compounds are available from the authors in mg quantities.

(C) 2010 by the authors; licensee MDPI, Basel, Switzerland. This article is an Open Access article distributed under the terms and conditions of the Creative Commons Attribution license (http://creativecommons.org/licenses/by/3.0/). 